\title{
Voice and Register In Little Dorrit
}

I:

N THE LAST twenty or thirty years interest in the analysis of narrative has shifted from the structure of plot and character to narrative situation, the act of speaking through which a fictional world is constructed. But this shift has done little to overcome the basic dualism of narrative theory. Through the dichotonn of narrative discourse and represented reality the categories of analysis come to refer to two disparate ontological realms: that of textual enunciation, and that of a represented world which is in some sense extralinguistic and prior to the form of its presentation. Even when "presented world" is placed within quotation marks, to indicate the pseudoreferential status of literary signification, the catcgory remains ambivalent; the coherence of the fictional world is seen not as a constructed and conventional coherence but as an effect of the coherence of the real world.

The Polish theoretician Janusz Stawiniski has argued that as long as narrative is understood as representation rather than as discourse, the basic explanatory categories of narrative theory will be taken directly from levels of concretization which are themselves in need of explanstion. These categories consist of totalities which have already come into being on the basis of previons interpretative steps. Consequently;

One can treat the aarrator as though he had a substantial existence outside the narrative, and talk of his attitude toward the represented world as an epistemological or moral relation, without regard for the circumstance that this is above all a cluster of semantic relations between eertain anits of the narrative utterasce. One can treat in the same way other elements of epic representation like time, space, the characterological units of a fgure, and so on ... These are all too often interpretations of the second, third, or even higher degree, and they take as their object penenomena which have already, in the coarse of concretization by the resder, been built above the level of the text. ${ }^{2}$

${ }^{1}$ Literatur als Systew sud Proseff, trans. Rolf Fieguth (Manich, 1975), p, 93. English translations are my own. 
However, Slawiński believes that the "semantic" conception of narration developed by the Russian Formalists is capable of overcoming this dualism, In Ejkenbaum's work on skaz, for example, the categories of "plot" and "narrator" work as "semantic constructions of the narrative discourse, whose mode of being is precisely that of the process of this discourse. The narrative work is not the sum of two heterogeneous spheres, the 'stylistic' and the 'represented'; it is a homogeneous totality which can be characterized in every one of its elements as utterance."2

I want to suggest two conditions under which I think such a unitary conception of the literary text is possible. The first concerns the status of the concept of discourse itself. The structuralist orthodoxy of our century places discourse (parole) in opposition to language as a systemic institution made up essentially of the formal phonological, grammatical, and morphosyntactic systems, and excluding semantics and the relation of language to its context. Discourse can therefore only be understood as the contingent and indeterminate surface realization of an essential deep structure. The language system is rulc-governed, discourse is not. For literary theorists, however, this has tended to be a relatively unfruitful conception of discourse, since it sharply separates literary discourse, which we know to be highly structured by the literary genres, from the apparently unstructured realm of nonliterary discourse.

An alternative conception of discourse as a systematically codified process can be drawn from a developing sociolinguistic tradition. The seminal figure here is Vološnov, who proposed that the universe of discourse is structured by genres of discourse, which he defined as normatively structured clusters of formal, contextual, and thematic features, "ways of speaking" in a particular situation; each genre is stratified as a social practice through the importance of "language etiquette, speech tact, and other forms of adjusting an utterance to the hierarchical organization of society." The kinds of meaning that can be produced are therefore determined by the structure of these rule-governed formations. This concept has been given greater precision through Halliday's development of the concept of register. Register is the semantic potential recurrently associated with a given situation type. ${ }^{4}$ It is marked by formal characteristics but "the distinction between one register and another is a distinction of what is said as much as of how it is said, without any enforced separation between the two" (p. 34). In this theory the context is conceived semiotically as a situation type, that is, a "constel-

\footnotetext{
${ }^{2}$ Slawingki, pp, 85-86.

${ }^{3}$ V. N. Volosinov, Marxism and the Philosophy of Language, trans. Ladislav Matejka and I. R. Titunik (New York and London, 1973), p. 21. V. N. Vološinov was a pseudonym for Mikhail Bakhtin.

4 M. A. K. Halliday, Langaage as Social Semiotic (London, 1978), p. 111; hereafter cited in the text.
} 
lation of meanings deriving from the semiotic system that constitutes the culture" (p. 109). This constellation can be analyzed in terms of the three variables of fietd, tenor, and mode, which "represent in systematic form the type of activity in which the text has significant function (field), the status and role relationships involved (tenor), and the symbolic mode and rhetorical channels that are adopted (mode)" (p. 122). The meaning of a piece of language is a function of the interaction of all of these variables. Language is therefore not a netutral or transparent medium, nor is it "an aggregate of conventional forms of expression superposed on some underlying content by 'social factors' of one kind or another" (p. 111). Every utterance is relative to a particular generic configuration which specifies normal relations of authority between speakers enunciating certain kinds of meanings in formulations appropriate to that kind of situation. The specific means and conditions of signification are therefore crucially involved in the production of meaning. This conception of the systematic codification of discourse should in fact be much more acceptable to literary theorists concerned with the particular ways in which literary discourse is shaped by the norms and conventions of genre and familiar with a number of registers-such as prayer, sermons, riddles, chants, and jokes-which are situated midway between literary and everyday discourse.

The second condition for a unitary conception of the discursive structure of literary texts is that literature be understood as a discourse which transforms other structures of discourse. This means that its raw material, its "content," would not be of a different order of being from itself. Literature would be seen as a metadiscourse working on prior systems which are organizations both of values and of positions of enunciation of those values. Consequently its high-order constructs of plot, character, narrator, space, time, and so on would need to be regarded as effects of the conventions of a particular genre of literary discourse, as reality-effects produced in the intertextual operation of one discourse upon another.

By using the concept of register we can analyze the text as a play of voices, that is, of utterances made from shifting positions specified by the registers the text invokes. Thesc positions are not necessarily actualized as those of a personified speaker : they are positions appropriate to a kind of speaker. The concept of voice, which was first systematically used by Bakhtin, has an advantage over traditional concepts such as point of view in that it is not in the first instance subordinate to concretizations drawn from a represented world, that is, to the "consciousness" or "vision" of characters or the narrator. There is, therefore, no sharp division betwcen discourse which is assigned, directly or indirectly, to a character and discourse which has its source in other texts. The narra- 
tive process can be theorized as a unified structure which knits together heterogeneous discourses; everything in the text is language.

Free indirect discourse, which became a major narrative device only in the nineteenth century, is of particular interest for the linguistic analysis of narrative in that it foregrounds the number of different contexts of enunciation from which the discourse of the text originates. It can most economically be described as a "dual voice" situated between narrative and represented voice and combining aspects of the homogeneous modality of indirect speech (the conformation of the tense sequence and personal pronotuns in the embedded clause to those of the main clause) with aspects of the split modality of the quoting of direct speech (deictics referring to the context of the quoted speech; the use of exclamations, incomplete sentences, oral intonation patterns, etc.). ${ }^{5}$ It is this ambivalence both of grammatical structure and of perspective which emphasizes the shifting directionality of narrative. Roland Barthes has in fact argued that this sense of direction is characteristic only of the classical novel, although I think that the indeterminacy of the modern text could be seen as a special case of the plural voice. According to Barthes:

In the classic text the majority of the utterances are assigned an origin, we can identify their parentage, who is speaking : either a consciousness (of a character, of the author) or a culture (the anomymous is still an origin, a voice ...).... The best way to conceive the classical plural is then to listen to the text as an iridescent exchange carried on by multiple voices, on different wavelengths and subject from time to time to a sudden dissolve, leaving a gap which enables the utterance to shift from one point of view to another, without warning. ${ }^{6}$

An analysis of the following extended passage from Little Dorrit will demonstrate the way in which these tonal shifts correspond to a play of quotations from or allusions to a number of different registers.

Arthur Clennam went on to the present purport of his visit; namely, to make Plornish the instrument of effecting Tip's release, with as little detriment as possible to the self-reliance and self-helpiulness of the young man, supposing him to possess any remnant of those qualities: without doubt a very wide stretch of supposition, 7

The last phrase initiates the first major shift of voice in this passage. Subjective adverbs or adverbial phrases of assertion like "without

${ }^{5}$ Cf. Roy Pascal, The Dral Voice (Manchester, 1977), and Ann Banfield, "Narrative Style and the Grammar of Direct and Indirect Speech," Foundations of Language, 10 (1973), 1-39. For my use of the concept of modality, cf. R. Hodge and G. Kress, Language as Ideology (London, 1979), pp. 85 and 91.

6 S/Z: An Essoy, trans, Richard Miller (New York, 1974), pp, 41-42.

${ }^{7}$ Charles Dickens, Little Dorrif (1857; rpt. Harmondsworth, 1967), pp, 18182 ; hereafter cited in the text. 
doubt" tend to function as indices of free indirect discourse. ${ }^{8}$ The "supposition" which in this phrase ironically negates that of the preceding phrase may either be Clennam's or that of a moral spokesman whose voice is suddenly foregrounded. More probably, it is a fusion of the two, in which Clennam's opirion is supplemented by a voice more open and sarcastic than his own.

Plornish, having been made acquainted with the cause of action from the Defendant's own mouth, gave Arthur to understand that the Plaintiff was a "Chaunter" -meaning, not a singer of anthems, but a seller of horses-and that he (Plornish) considered that ten shillings in the pound "would settle handsome," and that more would be a waste of money. (p. 182)

The capitalization of "the Defendant" and "the Plaintiff" perhaps indicates that the intonational stress is a quotation from Plornish, who is in awe of the legal register he is adopting. If that is so, then this sentence contains three different modes of rendition of Plornish' speechdirect speech, indirect speech, and free indirect discourse in addition to the parenthetical voice of the authoritative narrator.

The Principal and instrument soon drove off together to a stable-yard in High Holborn...

The reference to Clennam's desire to "make Plornish the instrument of effecting Tip's release" is an internal quotation. In this elaborated form as a ponderous circumlocution it works at the same time as a quotation from legal jargon.

... where a remarkably fine grey gelding, worth at the lowest figure, seventy-five guineas (not taking into account the value of the shot he had been made to swallow for the improvement of his form), was to be parted with for a twenty-pound note, in consequence of his having run away last week with Mrs. Captain Barbary of Cheltenham, who wasn't up to a horse of his courage, and who, in mere spite, insisted on selling him for that ridiculous sum: or, in other words, on giving him away.

This sentence of free indirect discourse fuses the narrator's discourse with the hyperbolic discourse of horse trading. The parenthetical phrase - "not taking into account the value of the shot he had been made to swallow for the improvement of his form"--is of a higher degree of complexity. By its continuity with the free indirect discourse it seems to be from the same source, but the contradictory content indicates that the voice is that of the narrator miming the alien register.

Althotgh I have identified voice as having its source in secondary concretizations ("Plornish," "the narrator"), this in no way contradicts the principle of the priority of discourse over the quasi-real entities which are its effects, since in the novel the assignment of a source to

${ }^{8}$ Cf. Pascal, p. 10. 
discourse functions precisely as a means of constructing these totalities; they are confirmed by being produced. That the assignment of discourse to a character is a secondary operation subsequent to its identification as a register is indicated by the fact that the source of the free indirect discourse here is not immediately located. The passage continues:

Plornigh, going up this yard alone and leaving his Principal outside, found a gentleman with tight drab legs, a rather old hat, a little hooked stick, and a blue neckerchief (Captain Maroon of Gloucestershire, a private friend of Captain Barbary) ; who happened to be there, in a friendly way, to mention these little circumstances concerning the remarkably fine grey gelding to any real judge of a horse and quick snapper-up of a good thing, who might look in at that address as per advertisement.

To be a character is to be both a source of discourse and an object of discourse; but there is no necessity for the jargon of horse trading to have been located in a particular speaker. The source could equally well have been left indefinite, that is, assigned to a type of speaker. Every register specifies a limited number of positions of utterance appropriate to it, and these positions may vary or may not be further specified as an object of the discourse of the text. The continuation of the free indirect discourse after the description of Captain Maroon of Gloucestershire has the effect of simultaneously identifying him retrospectively as the source of the passage about the "remarkably fine gelding" and defining him as the kind of speaker who would be likely to fill the position of utterance appropriate to that register.

The basic unit of analysis that I am using is therefore not character but those normative genres of discourse which may or may not be assigned to a specific persona. In this passage I would identify four main registers : that of nineteenth-century realist narrative, that of commercial transaction, legal jargon, and cockney dialect. The narrative norm governs three distinct voices : that of a neutral narrator, that of the moralizing narrator who condemns Tip, and that of the narrator who parodies Captain Maroon. However, if the phrase "without doubt a very wide stretch of supposition" can be read as a fusion of the narrator's voice with Clennam's, then we could argue that there is also a direct correspondence between Clennam's perspective and the narrative norm. Legal jargon is assigned in one case, indirectly, to Plornish, and in the other case-the phrase about "the Principal and instrument"- to a narrative voice quoting and perhaps parodying itself. The jargon of horse trading is assigned indirectly to Captain Maroon; the Cockney dialect, which is technically not a register but which seems in this case to be functioning in the same way, is assigned directly to Plornish.

The interest of this typology is, I think, that it allows us to analyze the novel in terms of relations between different kinds of discursive 
authority, each producing specific reality-effects, and in particular between literary and nonliterary structures of discourse. The force of the norms of nineteenth-century narrative lies in their monologic authority. Through their projection of a world which is objective and external to the formal structures through which it is enunciated, they sustain an authoritative definition of the real as a moral universe. The other registers invoked in this passage are still subsumed beneath this authority ; but at the sanne time they work to break the monopoly of verisimilitude held by the omniscient narrator. Bakhtin's concept of dialogic discourse is relevant here: by this he means discourse which is oriented toward and in some way influenced by an alien discourse. ${ }^{9}$ Parody, stylization, the projected narrator, free indirect discourse-any discourse which stresses the act of speaking and its relation to other acts of speaking-would function as a kind of double voice. Clearly the distinction between monologic and dialogic discourse is one of degree, since I have argued earlier that all literary discourse is a relation to previous discursive structures. But we could define monologic modes of discourse in terms of the suppression of alternative ways of speaking and the reproduction of official norms, and dialogic modes in terms of the pluralization of the text and the transformation of official norms. Further, it is those registers specified as appropriate by the genre-in this case particularly the morally superior discourse of the omniscient narratorwhich tend to embody official values, whercas those registers drawn from other realms-particularly those which transgress stylistic decorum-tend to subvert the authority of the dominant discourse.

This dominant discourse now needs to be defined more precisely in terms of the options made possible by the genre. The form of the novel that Dickens developed was a complex hybrid, and despite the huge quantity of commentary on his work there is hardly any substantial analysis of the different subgenres which were fused in the making of this form. Schematically we could say that the major underlying subgenres are a multistranded form of picaresque derived basically from Smollett and a form of Gothic which perhaps owes more to current Victorian melodrama than to the Gothic novel proper. The characteristic structure of the Gothic form is the double time scale which links a surface plot to a second plot buried in the past (it is from this Oedipal plot structure that the modern detective story developed). The structure of the multistranded picaresque, on the other hand, is essentially synchronic, a juxtaposition of simultaneous narratives. What happens in the fusion of these two forms is that the principle of resolution of diachronically separate strands is extended to the synchronically separate

\footnotetext{
Mikhail Bakhtin, Problems of Dostoersky's Pootics, trans. R. W. Rotsel (Ann Arbor, Mich., 1973), pp. 153 ff.
} 
strands. The discourse of the novel knots together plot structures which are both temporally and spatially dispersed. Miss Wade formulates this double teleology early in Little Dorrit: "In our course through life we shall meet the people who are coming to meet $u s$, from many strange places and by many strangc roads . . . and what it is set to us to do to them, and what it is set to them to do to us, will all be done" (p. 63).

Amongst the plurality of narrative modes in Little Dorrit it is clearly the Gothic register which carries the burden of official moral authority. It serves as the vehicle for a moral melodrama centered on the figure of Little Dorrit and expounding the themes of filial love, forebearance, and the accomplishment of Duty. And the fatality of its unfolding turns the narrative itself into a representative and instrument of the ineluctable laws of moral retribution. The rhetoric of the Gothic register is a rhetoric of doom and judgment which is relativized only by its discordant juxtaposition with other registers.

At the same time, however, the Gothic mode permits the thematization of material which effectively subverts the surface moral code. This matcrial relates to a past which is suppressed and which thereby contaminates the present, producing the disorder which motivates the contingencies of the plot. It is thematized through a number of different strands of imagery. At the very center of the book is the image of the dead travellers in the mortuary at the Great Saint Bernard monastery, frozen in an eternal gesture. Similarly, the imagery of imprisonment refers not only to physical confinement but to the retardation of time. The light of Chapter i is not only imprisoned but is also "the light of yesterday week, the light of six months ago, the light of six years ago. So slack and dead!" (p. 46), and the mirror in Miss Wade's apartment is "so clouded that it seemed to hold in magic preservation all the fogs and bad weather it had ever reflected" (p. 376). Flora lives in a "sober, silent, air-tight house" pervaded by the smell of old rose-leaves and lavender (p. 186), and she herself is described, in a bold simile, as behaving "with a caricature of her girlish manner, such as a mummer might have presented at her own funeral, if she had lived and died in classical antiquity" (p. 192). Mrs. Clennam, finally, is the focus of a whole series of images of the obscure prescrvation of secrets: the watch with its admonitory inscription striving to force the past into the present; the cellars of the house and the strong room, "stored with old ledgers, which had as musty and corrupt a smell as if they were regularly balanced, in the dead small hours, by a nightly resurrection of old bookkeepers" (p. 95) ; and more generally the neighborhood of the house, the streets of which "seemed all depositories of oppressive secrets" (p. 596).

The secret which haunts the novel is, of course, brought to light in the dénouement which unfolds the suppressed narrative within the pres- 
ent in order to restore and complete the order of narrative. But this story of wills and codicils, with all its improbable complexities, can surely not be anything other than a rationalization, screening a repressed Oedipal configuration-a structure of the positions of symbolic Father, Mother, and Child and the relations of attraction and identification between them - which is the unconscious of the text. Part of the force of the Gothic mode, indeed, lies in this potential for bringing repressed material so close to the textual surface without ever breaking through it.

The most interesting identification in the suppressed story is that which the codicil makes between Little Dorrit and Arthur Clennam's real mother (p. 848). But the identification is in fact much more complex. Clennam's relationship to Little Dorrit is never that of a peer ; nor is it, as the difference in their ages might suggest, merely a paternal relationship. Rather, it is a component of a structure in which the relations of father/daughter and mother/child are fully reversible. When Clennam lies ill in prison, Little Dorrit announces herself to him as "your own poor child"; and yet she at once adopts a maternal role, nursing him "as lovingly, and GOD knows as innnocently, as she had nursed her father in that room when she had been but a baby, needing all the care from others that she took of them" (p. 825). The reference to the nursing of her father recalls a previous passage which invokes the myth of Euphrasia suckling her father, King Evander, during his imprisonment: "There was a classical daughter once-perhaps-who ministered to her father in his prison as her mother had ministercd to her" (pp. 273-74). Both of these passages state the strong paradox that the female child is the mother of its own father. They identify Clennam, the lover, with Mr. Dorrit; and in both cases the emphasis on the innocence of the act of nursing suggests the probable incestuousness of one or both of these rclationships. ${ }^{10}$

At the same time this transformation of irreversible parent/child relations into reversible and incestuous relations, both for Clennam and for Little Dorrit, works as a negation of sexuality insofar as it sublimates Little Dorrit as a de-eroticized mother-figure. In this sense it completes the lack left by Mrs. Clennam's vacating of the position of mother, and it reinforces that predominant Dickensian myth of the foundling who has lost his real parents. But if the sublimation accords closely with the official moral ethos of the novel, it nevertheless fails to displace Mrs.

$10 \mathrm{Cf}$. Dianne Sadoff, "Storytelling and the Figure of the Father in Little Dorrit," PMLA, 95 (1980), 240: "Little Dorrit's version of incest represents this double bond of incest-familial desire and the temporal collapse of generation. The narrative collapses the family onto two figures : the daughter whom the father seduces becomes the mother who nurtures him, while the fatherly figure of the law becomes, through regression, the son. This dyad combines all the roles possible in an incest matrix." 
Clennam from her gencrically and symbolically central role as a type of that other, randomly evoked figure of the suckling mother: the Capitoline she-wolf (p. 668). Equally threatening is the motherless lesbian, Miss Wade, whose "History of a Self-Tormentor" directly contradicts the moral authority of the narrative discourse by presenting a set of incompatible counterreadings. Only since Dostoevsky has it been possible for the seriousness of the moral melodrama built around Miss Wade and Tattycoram to be appreciated.

The other way in which the Gothic register allows for internal contradiction is a function of its position outside the representational mainstream of the nineteenth-century realist novel. Henry James expressed this neatly when he wrote of Our Mutual Friend that it was "so intensely written, so little seen, known, or felt," and contrasted the "habitual probable of nature" to the "habitual impossible of Mr. Dickens."11 Consider the following passage:

As he went along, upon a dreary night, the dim streets by which he went, seemed all depositorics of oppressive secrets. The deserted counting-houses, with their secrets of books and papers locked up in chests and safes; the banking-houses, with their secrets of strong rooms and wells, the keys of which were in a very few secret pockets and a very few secret breasts; the secrets of all the dispersed grinders in the vast mill, among whom there were doubtless plunderers, forgers, and trustbetrayers of many sorts, whom the light of any day that dawned might reveal; he could have fancied that these things, in hiding, imparted a heaviness to the air. The shadow thickening and thickening as he approached its source, he thought of the secrets of the lonely church-vaults, where the people who had hoarded and socreted in iron coffers were in their turn similarly hoarded, not yet at rest from doing harm; and then of the secrets of the river, as it rolled its turbid tide between two frowning wildernesses of secrets, extending, thick and dense, for many miles, and warding off the free air and the free country swept by winds and wings of birds. (pp. 596-97)

The reality-effects of this text-the structure of images imbued with a particular moral ethos-are effects specific to the Gothic genre. That genre constructs an order which emphasizes the subjective apprehension of a threatening environment, and the main verb of each of these three sentences is a verb of subjective perception : the streets "seemed" to Clennam; he "could have fancied"; he "thought of." By means of these verbs the text moves outward from the indicative mood to the subjunctive, and this movement toward the realm of the possible is constructed on a framework of Gothic to poi : crime, shadow, church vaults, graves, the river. In this process language takes on a large degree of autonomy, building up alternative worlds on the basis of collocations which are conventional for the genre. It is the stylized discursive pat-

11 Chapter ii in Selected Literary Crificism, ed. Morris Shapira, 2nd ed. (1963; rpt. Harmondsworth, 1968), pp. 32-33. 
terns of the genre, in other words, which enable the solidification of a reality which is clearly based in the rhetorical play of language: in the repetition of the word "secret"; in the assonance of "winds and wings of birds"; in the concealed iambic pentameters of the second half of the third sentence. In this mode the claim to linguistic transparency is considcrably weaker than in the classic nineteenth-century realist text. Dickens anchors the world of his novels in discourse in a way and to an extent unthinkable in the novels of Flaubert or Eliot or Tolstoy.

This autonomization of language is of course not restricted to the Gothic genre, although it is arguable that the peculiar ontology of the Gothic mode provided much of the antirepresentational impetus of Dickens' writing. Much of the comic force of his novels depends on a similar process of literalization of the hypothetical or the figurative. For example, young John Chivery is described by his mother as sitting among the clotheslines in his backyard because "he feels as if it was groves." The phrase is later quoted literally by the narrator: "Here the good woman pointed to the little window, whence her son might be seen sitting disconsolate in the tuneless groves" (pp. 303-04). A more extended example of this playing of literal against figurative meanings is the description of Mr. F.'s Aunt:

An amazing little old woman, with a face like a staring wooden doll too cheap for expression, and a stiff yellow wig perched unevenly on the top of her head, as if the child who owned the doll had driven a tack through it anywhere, so that it only got fastened on. Another remarkable thing in this little old woman was, that the same child seemed to have damaged her face in two or three places with some blunt instrument in the nature of a spoon; her countenance, and particularly the tip of her nose, presenting the phenomena of several dints, generally answering to the bowl of that article. (p. 198)

Here the initial analogy with a doll generates a suppositious owner of the doll who is then linked with a series of predicates; and this chain moves so far away from the original figurative status of the association that Mr. F.'s Aunt does indeed assume the qualities of a doll, and becomes the inhabitant of an uncertain realm somewhere between the animate and the inanimate. A similar process turns Mrs. Merdle synecdochally into a bosom and by a further metonymic extension into a display case for jewelry (p. 293).

Through these devices the novel is able to a certain extent to subvert that monolithic moral reality carried predominantly (but contradictorily) by the Gothic mode. This subversion is in fact thematized in Little Dorrit through the opposition of official to nonofficial linguistic forms. Official language is conceived in terms of the avoidance of the taboo: Dorrit erects a wall of "genteel fictions," "elaborate forms," and "ceremony and pretence" against his knowledge that his daughters 
work (p. 114). After the family's rise to wealth Fanny, speaking in accordance with Mrs. General's regime of linguistic censorship, will refer to Clennam as "that vcry objectionable and unpleasant person, who, with a total absence of all delicacy, which our experience might have led us to expect from him, insulted us and outraged our feelings in so public and wilful a manner on an occasion to which it is understood among us that we will not more pointedly allude" (p. 506). Circumlocution of this order becomes a generalized social theme in the description of the Circumlocution Office: the self-perpetuation of the governing class is seen to depend upon the self-perpetuating proliferation of bureaucratic language.

These forms of the official are adequately treated at an overt thematic level. A more important subversion of the ideological atthority of monologic forms of language occurs, however, through the value given to the opposition between written and spoken forms, and in particular the stress on idiosyncratic styles of specch, either directly represented or incorporated into the narrative discourse. The speech of many of the lower-class characters-that of the Plornishes, for example-is a deformation of standard forms and so works both as parody and as a simple comic incongruity. The really complex idiolects are those of Flora and Mr. F.'s Aunt. Flora's rambling strings of free association are almost impenetrable because she in fact speaks both parts of a dialogue. This means that she can assume total comprehension of her presuppositions because there is no need of a response from the actual interlocutor whom she uses as a prop. In the case of Mr. F.'s Aunt this tendency to hermeticism becomes complete. This lady has "a propensity to offer remarks in a deep warning voice, which, being totally uncalled for by anything said by anybody, and traceable to no association of ideas, confounded and terrified the mind. Mr. F.'s Aunt may have thrown in these observations on some system of her own, and it may have been ingenious, or even subtle: but the key to it was wanted" (p. 199). The failure of signification undermines the rationality of the novel's moral universe, as a kind of thrcatening madness. And it is in this very opacity of the signifier that much of the violence and the ncurotic energy that underlie the text are able to rise to the surface.

To summarize : it is in the articulation of different modes of language -different registers-that the reality-effects and the fiction-effects of the literary text are generated. This articulation involves relations of dominance and subordination between registers, and this clash of languages is a clash of realities, that is, of moral universes. Representational narrative is not exempt from the principle of the analytic priority of structures of language over secondary concretizations like plot, character, or narrator. Indeed, I would argue that the precondition for a 
tunitary conception of the literary text is that its "content" be under stood, not as the material of reality or experience but as structures o discourse which are reproduced or transformed in the discourse of thi text.

Dickens' sensitivity to register and to the linguistic foundations o narrative make him a paradigmatic example for the analysis of literary discourse. The theory which underpins this analysis will be strength. ened as linguistics comes to deal more rigorously with the systematic codification of discourse and as literary criticism in its turn is able tc concentrate on the elaboration and transformation of these codes in the more complex genres of literary discourse.

Murdoch University, Western Australia 


\section{University Library}

\section{- M M N E R VA A gateway to Melbourne's research publications}

Minerva Access is the Institutional Repository of The University of Melbourne

Author/s:

FROW, JOHN

Title:

Voice and Register in 'Little Dorrit'

Date:

1981

Citation:

Frow, J. A. (1981). Voice and register in 'Little Dorrit'. Comparative Literature, 33(3), 258-270.

Publication Status:

Published

Persistent Link:

http://hdl.handle.net/11343/34221 